\title{
Identification of carotenoid pigments of pumpkin grown in the South of Russia
}

\author{
Lyudmila Rodionova ${ }^{1}$, Irina Sobol ${ }^{1}$, Lyudmila Donchenko $^{1}$, and Natalia Limareva ${ }^{2, *}$ \\ ${ }^{1}$ Kuban State Agrarian University, Faculty of Processing Technologies, 350044 Krasnodar, Russia \\ ${ }^{2}$ North-Caucasus Federal University, Institute of Service, Tourism and Design, 357500 Pyatigorsk, Russia
}

\begin{abstract}
The article presents the results of studies of changes in the vitamin composition of pumpkin, grown in the Kuban region. Standard and modern methods of physical and chemical analysis were used in the research. It is shown that the nutritional value of this raw material allows to maintain its nutritional value for a long time. Differential determination of carotenoid pigments contained in pumpkin fruits was carried out. The quantitative characteristics of carotenoids were established and the predominant carotenoid pigments for the studied pumpkin varieties were specified.
\end{abstract}

\section{Relevance of the theme}

Pumpkins belong to the Cucurbitacea family. There are six cultivated species, of which three are wide spread: C. maxima Duch-large-fruited, medium and lateripening, forage and dining; C. Pepo L.-table and fforage, early and middle-ripening; C. moschata Duchnutmeg pumpkin, table, late and middle-ripening.

In Southern Russia, in particular in the Kuban region, two main species are cultivated: C. maxima Duch and C. moschata Duch. Currently, there is work by different researchers including: Kahana B. I., Filova A. A., Serdyuk T. L. and others on the chemical composition of pumpkin, which is represented by such indicators as the content of dry substances, monosaccharides, pectin, hemicellulose, fiber, mineral salts, trace elements, water and fat-soluble vitamins (ascorbic acid, thiamine, Riboflavin, nicotinamide, Niacin, carotenoids, tocopherol, ergosterol) $[1,2,3,4]$.

Pumpkin fruits are rich in sugar (up to $12 \%$ ), starch (up to $20 \%$ ) and carotenoids $(5-18 \mathrm{mg} \%$ ). They are characterized by low titratable $(0.6-1.4 \%)$ and high active acidity ( $\mathrm{pH}$ 5.9-7.5). The amino acid composition of pumpkin pulp [5], which includes: tryptophan, lysine, histidine, arginine, aspartic acid, threonine, serine, glutamic acid, Proline, glycine, alanine, cystine, valine, methionine, isoleucine, leucine, tyrosine, phenylalanine, aminobutyric acid was studied. The pulp of pumpkin fruit includes all essential amino acids, the amount of which is $26.6-29.8 \%$ of the total amount of amino acids. Among the free amino acids there is a fairly rare amino acid - $\operatorname{sarcosin} 3,6 * 10-3 \%$.

It is known that pumpkin fruits contain a significant amount of carotenoids, coloring substances related to carotene, and $60-70 \%$ of them are biologically active [6, $7,8,9]$. An interesting feature of the pigment-proteinlipid complex is its high lability; it undergoes quite natural changes throughout the life of plants [10]. Recent studies suggest that the process of photosynthetic phosphorylation is closely related to both green and yellow pigments. This is in accordance with the fact that in photochemical reactions, the pigments of the phytochromoprotein complex participate as an integral photosynthetic unit.

From experimental data it is known that carotene in the green parts of plants is formed only in the light. In fruits, the formation of carotene can occur in the absence of light. The primary impetus for the formation of carotene is a change in carbohydrate metabolism, leading to a significant accumulation of soluble carbohydrate concentration. The excess of sugars, apparently, changes the intracellular physiological relations in the direction favorable for the synthesis of carotenoid coloring substances $[11,12,13]$.

The functionof carotenoid dyes in photosynthesis was proved by Detton and Mannig [10]. Their conclusions were subsequently confirmed by Emerson and Lewis [14]. However, the role of carotene in plants is not limited to its function in photosynthesis. Kohl and Vent $[10,15]$ found that carotene, which intensely absorbs the rays of the violet-blue part of the spectrum, protects amylase from their destructive effects. The role of carotene in the oxidation of unsaturated fatty acids was noted by Franco [16] and subsequently confirmed by other researchers. Joyet-Laverne argues that carotene provides a balance between the reduced and oxidized forms of glutathione in a living plant cell.

The results of numerous studies have shown that carotenoid dyes are widespread in the plant world. Their presence is characteristic of many plants, in which they are often contained in the form of very complex mixtures of related in structure and color pigments of the carotene series. Thus, the structure of their molecule is based on a polymethine chain composed of four isoprene residues,

\footnotetext{
*orresponding author: $\underline{\text { nlimareva } @ \text { pfncfu.ru }}$
} 
the ends of which are adjacent to the $\beta$-ionic, $\alpha$-ionic or pseudoionic cycles, both unsubstituted and containing mainly hydroxyl groups $[17,18,19]$. In the biosynthesis of terpenoids, including carotenoids, the precursor is isopentyl pyrophosphate, being the main 5-carbon compound from which the carotenoid molecule is built.

Biosynthesis of isopentyl pyrophosphate occurs in the usual way through the formation of mevalonic acid, which is synthesized as a result of successive addition of three molecules of acetyl-COA to each other. This is followed by isomerization of isopentyl pyrophosphate in dimethylallylpyrophosphate under the influence of the enzyme isopentylacetate and subsequent condensation of farnesyl pyrophosphatases in geranyl and then farnesylpyrophosphate. Some researchers believe that one of the cyclic precursors of carotenes is an unsaturated hydrocarbon containing 40 carbon atomslycopersene, synthesized from two molecules of geranylgeranyl pyrophosphate. According to other researchers, the object of cyclization is lycopene [20].

Currently, it is well known That the A-provitamin biological activity of carotene dyes depends on the presence of unsubstituted $\beta$-ion cycles in the molecule, i.e. those structural elements that provide the formation of vitamin A molecules during the conversion of carotene (cleavage by the Central double bond in humans and animals). Maximum A-provitamin activity has $\beta$-carotene, half as much- $\alpha$-carotene, $\gamma$-carotene, carotenoid cryptoxanthin and some other representatives of this group of compounds.

The purpose of the research was an in-depth study of the chemical composition of different varieties of pumpkin grown in the Kuban region. Studies included qualitative determination of the chemical composition and some vitamins, as well as studies to determine the differentiated composition of carotenoids of different varieties of pumpkin, combined by species.

\section{Research methods}

Standard and modern methods of physical and chemical analysis of plant raw materials were used in the study of the selected varieties. Studies were conducted on 240 samples in 2016, 2017 and 2018 in at least 6 repetitions. Samples of pumpkin fruits were selected in the technical degree of maturity. Determination of carotenoids was carried out immediately after harvesting and after storage. The optimal storage mode was carried out at a temperature of $+10^{\circ} \mathrm{C}$, relative humidity of $70 \%$ in the refrigerator.

Pumpkin samples for study were prepared as follows. Segments were cut from ten fruits of each variety, crushed, and and an average sample weighing $100 \mathrm{~g}$ Sample of crushed blend was extracted with acetone until complete bleaching, and then the resulting solution was concentrated to $5-7 \mathrm{ml}$ in an oxygen-free environment $d$. The resulting solution was applied to a silufol plate was used for holding the thin-layer chromatography, which was performed with the use of different combinations of solvents reported in the literature.

The material obtained by chromatography was removed from the plates and subjected to elution with various solvents (chloroform, gasoline, ethanol, methanol), after which spectrophotometry was performed on the Spekord-40M device. Column chromatography was used to confirm the data obtained from the spectra. Carotene isomers were separated on air-dry aluminium oxide. Aluminium oxide was calcined for two hours at a temperature of $2000 \mathrm{C}$, then cooled with continuous stirring for 15-30 minutes. The resulting aluminum oxide was filled with a column with a diameter of $15 \mathrm{~mm}$ and a height of $10-15 \mathrm{~cm}$.

Benzene eluate of carotene removed from the plates of Silufol with Rf 96-98 in an amount of 2-3 cm3 was applied to the surface of the column and was shown with gasoline to a completely clear separation of zones. The column was dried, the adsorbent column was pushed out, cut along the boundaries of the manifested bands and eluted with gasoline and chloroform. Eluates were subjected to spectrophotometry on the Spekord 40M instrument and compared with the data of the obtained spectra. Spectral data and chromatographic characteristics were processed by comparison with the literature data ( $\mathrm{Rf}$ and spectral characteristics).

\section{Results and discussion}

Due to the fact that carotenoids are the most important indicators of pumpkin quality, they were studied indepth. The study was not reflected in the literature. In the study of different varieties of pumpkin grown in the Kuban region, it was determined that the content of carotenoids varies within $10-35 * 10-3 \%$. Especially rich in carotenoids are such varieties as Marble, Nutmeg, Vitamin, winter Table. These varieties are characterized by a sufficiently high level of carotenoids and better organoleptic evaluation. In the analysis of intact carotenoids during storage of different varieties of pumpkins found that the pumpkin species C. maxima which include pumpkin varieties Marble and Winter Table have better keeping quality and remain rich in carotenoids throughout the whole storage period (120 days) (table 1).

Table 1. Changes in pumpkin carotenoids during long-term storage in optimal conditions (temperature $100^{\circ} \mathrm{C}$, relative humidity $70 \%$, storage time-up to 120 days).

\begin{tabular}{|c|c|c|c|c|}
\hline \multicolumn{5}{|c|}{ Change in the amount of carotenoids during storage, \% } \\
\hline Species of pumpkin & $\begin{array}{c}\text { At the beginning of } \\
\text { storage }\end{array}$ & $\begin{array}{c}\text { After } 2 \text { months } \\
\text { storage }\end{array}$ & $\begin{array}{c}\text { After 4 months } \\
\text { storage }\end{array}$ & $\begin{array}{c}\text { After } 6 \text { months } \\
\text { storage }\end{array}$ \\
\hline C.maxima Duch & $17,7 * 10^{-3}$ & $21,5 * 10^{-3}$ & $14,8^{*} 10^{-3}$ & $10,7 * 10^{-3}$ \\
\hline C. moschata Duch & $19,9^{*} 10^{-3}$ & $23,1^{-3} 10^{-3}$ & $18,6^{*} 10^{-3}$ & $13,3 * 10^{-3}$ \\
\hline
\end{tabular}


Table 2. Coloring of bands at chromatography of different types of pumpkin on thin-layer chromatography.

\begin{tabular}{|c|c|c|c|}
\hline № & Band color & Rf & Preliminary identification \\
\hline \multicolumn{2}{|c|}{ Pumpkins of the species C. maxima } \\
\hline 1 & Yellow & 0,11 & Violaxanthin \\
2 & Yellow-brown & 0,27 & Flavoxanthin \\
3 & Pale yellow & 0,37 & Unidentified \\
4 & Lemon yellow & 0,56 & Luteoxanthin \\
5 & Amber-yellow & 0,66 & Polyol \\
6 & Bright yellow & 0,78 & $\beta$-carotene, monoepoxide \\
7 & Bright lemon yellow & 0,96 & $\alpha$-carotene-5,6 monoepoxide \\
8 & Bright orange & 0,99 & $\alpha$-carotene \\
\hline \multicolumn{2}{|c|}{ Pumpkins of the species C. moschata } & Lutein \\
\hline 1 & Yellow & 0,34 & Violaxanthin \\
2 & Bright yellow & 0,49 & Lutexanthin \\
3 & Pale brown-yellow & 0,62 & Polyol \\
4 & Pale yellow & 0,78 & $\alpha$-carotene \\
5 & Pale yellow & 0.98 & \\
6 & Bright orange
\end{tabular}

It was found that in the first months of storage, there is an accumulation of carotenoids, which correlates with the dynamics of sugars and is especially pronounced for varieties with long storage life.

In differentiated studies conducted using thin-layer chromatography, after the separation of carotenoid pigments on the plates, a different number of bands were obtained that were clearly visible in daylight. They had different intensity coloring in yellow-orange tones. Therefore, the mixture of pigments, depending on the type of pumpkin was divided into a different number of bands. The chromatograms of the C. maxima pumpkin (Marbled and Winter Table) were divided into 8 bands, and the chromatograms of the C. moschata pumpkin form 6 bands.

The main indicator for the identification of carotenoids is the absorption spectra of their solutions in organic solvents. Almost all carotenoids have three absorption peaks in the visible spectrum. The position of these maxima is determined by the number of double bonds. When identifying carotenoids, i.e. comparing their absorption maxima in various solvents with the literature data, the following carotenoids were identified in pumpkins of the species C. moschata, according to preliminary identification: lutein, violoxanthin, flavoxanthin, luteoxanthin, polyol, $\alpha$-carotene. In these varieties of biologically active carotenoids was found only $\alpha$-carotene, which has a reduced biological activity compared to $\beta$-carotene, but the presence of a significant amount once again confirmed the nutritional value of pumpkin fruits and the need to use them as widely as possible in the diet.

The following pigments were identified in the pumpkins of the species C. maxima (Marbled and Winter Table): violoxanthin, flavoxanthin, luteoxanthin, polyol, $\beta$-carotene monoepoxide, $\alpha$-carotene-5,6

Table 3. Absorption maxima of C. moschata pumpkin carotenoid pigments during identification in various solvents.

\begin{tabular}{|c|c|c|c|c|c|c|c|c|c|}
\hline \multirow[t]{2}{*}{ № } & \multicolumn{2}{|c|}{ Chloroform } & \multicolumn{2}{|c|}{ Ethanol } & \multicolumn{2}{|c|}{ Methanol } & \multicolumn{2}{|c|}{ Gasoline } & \multirow[t]{2}{*}{ Identification } \\
\hline & $\begin{array}{l}\text { Experiment } \\
\text { al data }\end{array}$ & $\begin{array}{c}\text { Literatu } \\
\text { re } \\
\text { data }\end{array}$ & $\begin{array}{l}\text { Experime } \\
\text { ntal data }\end{array}$ & $\begin{array}{c}\text { Literat } \\
\text { ure } \\
\text { data }\end{array}$ & $\begin{array}{c}\text { Experi } \\
\text { mental } \\
\text { data }\end{array}$ & $\begin{array}{c}\text { Literature } \\
\text { data }\end{array}$ & $\begin{array}{c}\text { Experi } \\
\text { mental } \\
\text { data }\end{array}$ & $\begin{array}{c}\text { Literat } \\
\text { ure } \\
\text { data }\end{array}$ & \\
\hline 1 & $\begin{array}{l}487,0 \\
455,0 \\
430,0\end{array}$ & $\begin{array}{l}487,0 \\
456,0 \\
428,0\end{array}$ & $\begin{array}{l}470,0 \\
448,0 \\
424,0\end{array}$ & $\begin{array}{l}470,0 \\
446,0 \\
420,0\end{array}$ & Lutein & $\begin{array}{c}473,0 \\
444,0 \\
418,0,0\end{array}$ & - & - & Lutein \\
\hline 2 & $\begin{array}{l}480,0 \\
450,0 \\
424,0 \\
\end{array}$ & $\begin{array}{l}482,0 \\
451,0 \\
424,0 \\
\end{array}$ & $\begin{array}{c}474,0 \\
4443,0 \\
418,0 \\
\end{array}$ & $\begin{array}{l}471,0 \\
442,0 \\
417,5 \\
\end{array}$ & $\begin{array}{l}\text { Violaxa } \\
\text { nthin }\end{array}$ & $\begin{array}{l}469,0 \\
440,0 \\
415,0 \\
\end{array}$ & - & - & Violaxanthin \\
\hline 3 & $\begin{array}{l}460,0 \\
430,0 \\
409,0\end{array}$ & $\begin{array}{l}460,0 \\
433,0 \\
409,0\end{array}$ & $\begin{array}{l}448,0 \\
424,0 \\
406,0\end{array}$ & $\begin{array}{l}449,0 \\
425,0 \\
406,0\end{array}$ & - & - & - & - & $\begin{array}{c}\text { Luteoxanthin } \\
\text { (5:6 } \\
5: 8 \text { - zeaxanthin } \\
\text { diepoxide) }\end{array}$ \\
\hline 4 & $\begin{array}{l}466,0 \\
430,0 \\
409,0\end{array}$ & $\begin{array}{l}469,0 \\
429,0 \\
409,0\end{array}$ & $\begin{array}{l}480,0 \\
446,0 \\
408,0\end{array}$ & $\begin{array}{l}480,0 \\
446,0 \\
406,0\end{array}$ & $\begin{array}{l}496,0 \\
443,0 \\
420,0\end{array}$ & - & - & - & $\begin{array}{l}\text { Not identified, } \\
\text { may be } \\
\text { polyatomic } \\
\text { Alcohol -polyol }\end{array}$ \\
\hline 5 & $\begin{array}{l}482,0 \\
454,0\end{array}$ & $\begin{array}{l}483,0 \\
454,0\end{array}$ & - & - & - & - & $\begin{array}{l}470,0 \\
441,0\end{array}$ & $\begin{array}{l}471,0 \\
442,0\end{array}$ & $\begin{array}{c}\alpha \text { - carotene-5,6 } \\
\text { monoepoxide }\end{array}$ \\
\hline 6 & $\begin{array}{l}486,0 \\
455,0 \\
\end{array}$ & $\begin{array}{l}485,0 \\
454,0 \\
\end{array}$ & - & - & - & - & $\begin{array}{l}477,0 \\
448,0 \\
\end{array}$ & $\begin{array}{l}478,0 \\
447,0 \\
\end{array}$ & $\alpha-$ carotene \\
\hline
\end{tabular}


Table 4. Maxima of absorption of pigments of carotenoids of pumpkin of C. maxima type at identification in various solvents.

\begin{tabular}{|c|c|c|c|c|c|c|c|c|c|}
\hline \multirow[t]{2}{*}{ № } & \multicolumn{2}{|l|}{ Chloroform } & \multicolumn{2}{|l|}{ Ethanol } & \multicolumn{2}{|l|}{ Methanol } & \multicolumn{2}{|c|}{ Gasoline } & \multirow{2}{*}{$\begin{array}{l}\text { Identificatio } \\
\mathrm{n}\end{array}$} \\
\hline & $\begin{array}{l}\text { Experiment } \\
\text { al data }\end{array}$ & $\begin{array}{l}\text { Literatur } \\
\text { e } \\
\text { data }\end{array}$ & $\begin{array}{l}\text { Experime } \\
\text { ntal data }\end{array}$ & $\begin{array}{l}\text { Literat } \\
\text { ure } \\
\text { data }\end{array}$ & $\begin{array}{l}\text { Experime } \\
\text { ntal data }\end{array}$ & $\begin{array}{l}\text { Literatur } \\
\text { e } \\
\text { data }\end{array}$ & $\begin{array}{l}\text { Experi } \\
\text { mental } \\
\text { data }\end{array}$ & $\begin{array}{l}\text { Literat } \\
\text { ure } \\
\text { data }\end{array}$ & \\
\hline 1 & $\begin{array}{l}487,0 \\
455,0 \\
430,0\end{array}$ & $\begin{array}{l}487,0 \\
456,0 \\
428,0\end{array}$ & $\begin{array}{l}476,0 \\
448,0 \\
424,0\end{array}$ & $\begin{array}{l}476,0 \\
446,042 \\
0,0\end{array}$ & $\begin{array}{l}471,0 \\
443,0 \\
420,0\end{array}$ & $\begin{array}{l}473,0 \\
444,0 \\
418,0\end{array}$ & - & - & Lutein \\
\hline 2 & $\begin{array}{l}480,0 \\
452,0 \\
425,0\end{array}$ & $\begin{array}{l}482,0 \\
451,0 \\
424,0\end{array}$ & $\begin{array}{l}473,0 \\
443,0 \\
420,0\end{array}$ & $\begin{array}{l}471,0 \\
442,0 \\
417,0\end{array}$ & $\begin{array}{l}471,0 \\
423,0 \\
417,0\end{array}$ & $\begin{array}{l}473,0 \\
440,0 \\
415,0,0\end{array}$ & - & - & Violaxanthin \\
\hline 3 & $\begin{array}{l}450,0 \\
427,0 \\
417,0 \\
\end{array}$ & $\begin{array}{l}452,0 \\
430,0 \\
424,0 \\
\end{array}$ & $\begin{array}{l}474,0 \\
4443,0 \\
418,0 \\
\end{array}$ & $\begin{array}{l}471,0 \\
442,0 \\
417,5 \\
\end{array}$ & $\begin{array}{l}471,0 \\
442,0 \\
417,0 \\
\end{array}$ & $\begin{array}{l}469,0 \\
440,0 \\
415,0 \\
\end{array}$ & - & - & Flavoxanthin \\
\hline 4 & $\begin{array}{l}458,0 \\
431,0 \\
409,0 \\
\end{array}$ & $\begin{array}{l}459,0 \\
430,0 \\
426,0 \\
\end{array}$ & - & - & - & - & - & - & Not identified \\
\hline 5 & $\begin{array}{l}458,0 \\
431,0 \\
409,0\end{array}$ & $\begin{array}{l}460,0 \\
433,0 \\
409,0\end{array}$ & $\begin{array}{l}448,0 \\
424,0 \\
406,0\end{array}$ & $\begin{array}{l}449,0 \\
425,0 \\
406,0\end{array}$ & - & - & - & - & Luteoxanthin \\
\hline 6 & $\begin{array}{l}457,0 \\
430,0\end{array}$ & $\begin{array}{l}457,0 \\
430,0\end{array}$ & $\begin{array}{l}447,0 \\
421,0\end{array}$ & $\begin{array}{l}447,0 \\
422,0\end{array}$ & - & - & - & - & $\begin{array}{l}\text { Polyol } \\
\text { (polyhydric } \\
\text { alcohol) } \\
\end{array}$ \\
\hline 7 & $\begin{array}{l}484,0 \\
456,0\end{array}$ & $\begin{array}{l}485,0 \\
454,0\end{array}$ & - & - & - & - & $\begin{array}{l}478,0 \\
446,0\end{array}$ & $\begin{array}{l}478,0 \\
447,0\end{array}$ & $\begin{array}{l}\beta-\quad \text { carotene } \\
\text { hydroxy- } \\
\text { carotene } \\
\text { monoxide }\end{array}$ \\
\hline 8 & $\begin{array}{l}482,0 \\
454,0\end{array}$ & $\begin{array}{l}483,0 \\
454,0\end{array}$ & - & - & - & - & $\begin{array}{l}470,0 \\
441,0\end{array}$ & $\begin{array}{l}471,0 \\
442,0\end{array}$ & $\begin{array}{l}\alpha-\quad \text { carotene- } \\
5,6 \\
\text { monoepoxide }\end{array}$ \\
\hline 9 & $\begin{array}{l}486,0 \\
455,0\end{array}$ & $\begin{array}{l}485,0 \\
454,0\end{array}$ & - & - & - & - & $\begin{array}{l}447,0 \\
448,0\end{array}$ & $\begin{array}{l}448,0 \\
447,0\end{array}$ & $\alpha$ - carotene \\
\hline
\end{tabular}

monoepoxide, $\alpha$-carotene (table 2).

This type of pumpkin has a higher biological activity of carotenoids. In the composition of the detected pigments are: $\alpha$-carotene and $\beta$-carotene, monoepoxide. These isomers of carotene have significant biological activity; therefore they are more valuable for use in human nutrition.

Tables 3 and 4 show the absorption maxima determined by spectrophotometry in various solvents for comparison with the literature data.

These values confirm the preliminary identification by the composition of carotenoid pigments of different types of pumpkin grown in the South of Russia in the Krasnodar region. The position of these maxima is determined by the number of double bonds. When identifying carotenoids, i.e. comparing their absorption maxima in various solvents with the literature data in pumpkins of the species C. moschata were identified.

\section{Conclusions and proposals}

Thus, in determining the qualitative composition of pumpkin grown in the Kuban region were identified: lutein, violoxanthin, flavoxanthin, luteoxanthin, polyol, $\alpha$-carotene-5,6 monoepoxide, $\alpha$-carotene, and isomers of $\beta$-carotene. It was found that the proportion of carotene isomers $\alpha$-, $\beta$-is $85-90 \%$ of the total amount of carotenoids contained in pumpkin. At the same time, a large proportion ( $80 \%$ ) falls on $\alpha$-carotene. This ratio is noted for all tested varieties of pumpkin.

When conducting studies in the pumpkin of species C. maxima during storage, there is an accumulation of high sugar content, both total and invert, throughout storage corresponding to an accumulation of carotenoids. The cartenoids are stable and after six months of storage the level was the same as initial level. These varieties have the best keeping longevity. Consequently, pumpkins of the species C. maxima are recommended for long-term storage, and varieties belonging to the species C. moschata are recommended for use in the first months of storage.

\section{References}

[1] I.M. Asherov, Pumpkins Of Uzbekistan, Nauka, Tashkent (1979).

[2] I.M. Asherov, Potatoes and Vegetables, 2, 31 (1968).

[3] A.I. Filov, Potatoes and Vegetables, 12, 53 (1962).

[4] V.S. Chernetchenko, Watermelons, melons, pumpkins, Kharkiv book publishing house, Kharkiv (1954).

[5] V.P. Bordenyuk, B.M. Kahana, Effect of storage and cooking on amino acid composition of 
pumpkin fruit pulp, MIFBP AS USSR, Moskow (1978).

[6] A.L. Fel'dman, FoodTechology, 4, 33 (1977).

[7] T. Gordon Howard, .BauerFeind, CRC Crit. Rew. Food Sci. And Nutr., 18, 57 (1982).

[8] P. LewisEdwad, N. Sr. Elbert Elizabeth, J. Food Sci., 29, 715 (1964).

[9] M. Rosenberg, C.H. Mannhein, I.J. Kopolman, Lebesmitt, Wiss Technol, 17, 270 (1983).

[10] S.D. Balahovskij, N.A. Troickaya, Reports of the USSR Academy of Sciences, 82 (1952).

[11] G.V. Vil'shtedt, Carotenoids and coloring agents of bacteria and fungi, The main office of the chemical literature, Moskow (1936).

[12] A.N. Oparin, Collection of works on chemistry and biology, AS USSR, Moskow (1950).

[13] A.A. SHlyk, Determination of chlorophylls and carotenoids in green leaf extracts, Nauka, Moskow (1971).

[14] I.A. Kuhule, I.I. Windle, A.C. Waiss, J. Chem. Soc. B., 6, 613 (1969).

[15] D.A. Wof, D.C. Cornwell, Compar. Biochem. Phisiol., 16, 205 (1965).

[16] E.S. DellaMonica, P.E. McDowell, Food Technol., 19, 141 (1965).

[17] B.G. Savinov, F.L. Grinberg, Ukrainian chemical journal, XVI, 3, 358 (1950).

[18] B.G. Savinov, F.L. Grinberg, Isomerization of carotene, Successes of chemistry, Kiev (1948).

[19] YU.G. Skorikova, Polyphenols of fruits and berries and the formation of color product, Food Processing, Moskow (1973).

[20] S.N. Mihlin, Z.S. Grafskaya, E.V. Zavodskaya, Biochemistry, Moskow (1946). 